\title{
Habitat use and food partitioning of the fishes in a coastal stream of Atlantic Forest, Brazil
}

\author{
J. M. R. Aranha, D. F. Takeuti \& T. M. Yoshimura
}

Depto Zoologia, Setor de Ciências Biológicas, Universidade Federal do Paraná, CP 19.020,

CEP 81531-990, Curitiba, Brasil. Fax: 55(041)266-2042, E-mail: jmaranha@garoupa.bio.ufpr.br

Received 5-II-1998. Corrected 22-VI-1998. Accepted 13-VIII-1998.

\begin{abstract}
We analysed the fish assemblage in the "Mergulhão" stream (southern Brazil) with underwater observations for habitat use, considering water depth, current velocity, bottom type, shadow from vegetation cover, distance of stream-edge, and vertical position. Stomach contents or foregut content samples of the most abundant species were collected from 26 species ( 10 families). The fish assemblage occupied the bottom stream. The similarity analysis of spatial occupation of species grouped four habitat use guilds: A) "lambaris" (Astyanax sp. and Deuterodon langei), Characidium spp. (C. lanei and C. pterostictum) and Rineloricaria kronei used the bottom in deep sites and waters with middle current; B) Pimelodella pappenheimi and Corydoras barbatus used the bottom in sites with lower current; C) Mimagoniates microlepis used the surface of the water column; and D) Phalloceros caudimaculatus used shallow sites and waters without current. Species with few records were analysed descriptively. Diet similarity suggested seven trophic guilds: Microglanis sp. and Pimelodella pappenheimi: omniyorous/carnivorous guild; Corydoras barbatus: omnivorous/insectivorous guild; Characidium lanei: aquatic insectivorous guild, mainly aquatic insects; Mimagoniates microlepis: terrestrial insectivorous guild, mainly terrestrial insects; Deuterodon langei and Astyanax sp.: omnivorous/herbivorous guild; Rineloricaria kronei, Kronichthys subteres, Schizolecis guntheri, Hisonotus leucofrenatus and Pseudotothyris obtusa: herbivorous guild; and Phalloceros caudimaculatus: algivorous guild. When the guilds were similar, the species were generalists in diet and in habitat use.
\end{abstract}

Key words: Habitat use, feeding, resource partitioning, Atlantic Forest, coastal stream, Brazil.

Neotropical freshwater fishes are very diverse and fish assemblages are quite rich in this region. So the interspecific relationships are intricate in these communities (LoweMcConnell 1987).

Several researchers believe that competition would be an important ecological and evolutionary factor (e.g. Schoener 1974, Yant $e t$ al. 1984). Nevertheless, others believe that the environmental instability of the abiotic factors would reduce the importance of the competitive relationships (e.g. Connor \& Simberloff 1979, Strong 1980, Grossman et al. 1982, Wiens 1977).

The resource partitioning in a community may be important to the knowledge of the nature of these interrelationships (Schoener 1974). The most important dimensions of resource partitioning for fish assemblages are the habitat and trophic segregation (Ross 
1986), being the habitat segregation most important in freshwater than it is in marine environments (Horn 1972).

In Brazil, studies of microhabitat and/or trophic structure of freshwater fish assemblages have been increasing during the last few years, but few studies have been conducted in coastal streams (e.g. Costa 1987, Teixeira 1989, Sabino \& Castro 1990).

In this paper, the microhabitat use and trophic structure in guilds of the fishes were analysed in a coastal stream of the Atlantic Forest in Paraná State.

\section{MATERIALS AND METHODS}

The "Mergulhão" stream is a second order stream Atlantic Forest coastal stream in Antonina municipality (Paraná State, Brazil; $\left.25^{\circ} 17^{\prime} \mathrm{S}, 48^{\circ} 44^{\prime} \mathrm{W}\right)$, with very clear water, which allows underwater observations. In the studied area the contiguous vegetation is composed of trees and shrubs on the left edge and herbaceous plants on the right. The average depth is one meter, and the average distance between the edges is $5 \mathrm{~m}$.

This research was conducted in daylight in September and October 1993, and January and March 1994.

A grid with ten transects (adapted from Gorman \& Karr 1978; Fig. 1) with 80-130 point-samples was used for measuring four habitat variables and for observation of the fishes. The habitat variable measurements were the depth of water, current velocity, bottom type and shadow of vegetation cover. The depth was measured in centimeters and classified in categories of ten of centimeters $(1=0$ $10 \mathrm{~cm}$ to $9=80-90 \mathrm{~cm}$ ). The current velocity was measured with a Pitot tube at two centimeters under the surface and classified in four categories: 0 , imperceptible; 1 , slow $\left(0.00-0.25 \mathrm{~m} . \mathrm{s}^{-1}\right) ; 2$, moderate $\left(0.25-0.50 \mathrm{~m} . \mathrm{s}^{-1}\right)$; and 3 , fast $\left(0.50-0.75 \mathrm{~m} . \mathrm{s}^{-1}\right)$. The substrate or bottom type was classified in eight categories: 1 , sand; 2 , gravel; 3 , pebble; 4 , stone (less than $10 \mathrm{~cm}$ of diameter); 5 , rock $(10-25 \mathrm{~cm}) ; 6$, large rock (more than $25 \mathrm{~cm}$ ); 7, litter and 8 , trunk and branches. The shadow of the vegetation cover was recorded by the presence (1) or absence ( 0 ) of the vegetation itself or branches over the point-sample.

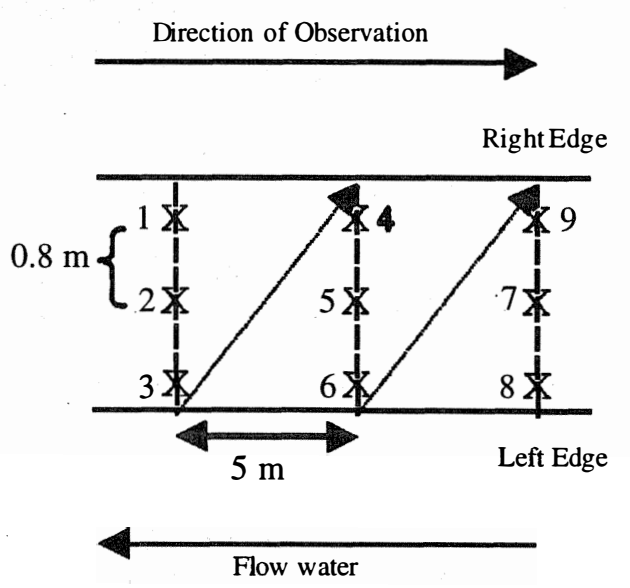

Fig. 1. Location of the sample-points in transects for measurement of variables of habitats and observation of habitat use. The grid has ten transects at $5 \mathrm{~m}$ intervals.

The underwater observations were done with mask and snorkel during $6 \mathrm{~min}$ in each point-sample, where we noted the number of fishes of each species, their distance from the water's edge and their vertical position. The distance from the water's edge was classified in three categories: 0 , nearest to right edge; 1 , mid-stream and 2, nearest to left edge. The vertical position was categorized as 1 (upper third of the water column), 2 (middle third), 3 (lower third) and 4 (bottom).

During the underwater observation, the feeding behaviour of the species was noted, and grouped using the same foraging tactic categories described by Sazima (1986).

After the observation, fishes were collected with fishing-nets, casting nets and sieves to study the fish assemblage and their diet.

The stomach or samples of the foregut contents of the most abundant collected species (when individuals were over ten) were 
examined, under estereoscopic microscope and optical microscope, to assign the feeding guilds by analysis by the occurrence methods, which the percent composition of each food item in the total number of the items found (Hyslop 1980).

Data Analysis: Chi-square goodness-offit-test was used to compare frequency distributions of habitat use in relation to the availability of each resource. Calculations of expected frequencies were based on the environmental features and the sample sizes were standardized to a total of 100 , as suggested in Gorman (1988). For this purpose, we used the data for each species and for all species together. All species analysis provided an assessment of how the assemblage used the available resources.

The similarity in the habitat use by species was estimated by the Morisita's measure (Smith \& Zaret 1982). A cluster analysis with UPGMA method (Romesburg 1990) was applied using the similarity data. The similarity of the percent composition of each food item was calculated using the Morisita's measure modified by Horn (Smith \& Zaret 1982) and the results were grouped by UPGMA method (Romesburg 1990) to determine the feeding guilds.

\section{RESULTS}

We collected 26 species belonging to 10 families in the "Mergulhão" stream (Table 1).

The underwater observations totalized 14 hours and 2462 observation records of Mimagoniates microlepis, Phalloceros caudimaculatus, Corydoras barbatus, Pimelodella pappenheimi, Rineloricaria kronei, Astyanax sp., Deuterodon langei, Characidium lanei and C. pterostictum. The accurate specific differentiation of Astyanax sp. and Deuterodon langei was impossible to do during the observations and they were treated together and designated here by "lambaris". Likewise, $C$. lanei and $C$. pterostictum were treated as Characidium spp.
The habitat variables that prevails in the "Mergulhão" stream were the sand-type substrate (category 1 ), current velocity till $0.5 \mathrm{~m} . \mathrm{s}^{-1}$ (categories 1 and 2) and depths between 40 and $60 \mathrm{~cm}$ (categories 5 and 6).

The significant differences in the habitat use, by species and by assemblage, in each environmental variable category and its mainly occurrence is showed in Table 2. The habitat use by the fish assemblage was significant to vertical position and the tendency to occupy the bottom was corroborated. "Lambaris" tended to occupy the bottom of deep stretches with moderate and fast current velocity. Mimagoniates microlepis preferred sites in the left edge with litter and trunk/branch substrate type, water surface and shaded areas. Characidium spp. preferred water with current more than 0.25 $\mathrm{m} / \mathrm{s}$ in deeper sites and occupied the bottom in unshaded areas. Pimelodella pappenheimi occupied the stream bottom in areas with sand, gravel and litter substrate types, water with current untill $0.25 \mathrm{~m} . \mathrm{s}^{-1}$ in unshaded areas with moderate depths. Corydoras barbatus occupied almost exclusively the stream bottom mainly the right edge, in litter and trunk/branch substrate type and waters whose current was lower than $0.25 \mathrm{~m} . \mathrm{s}^{-1}$. Rineloricaria kromei occurred in the right edge in unshaded deeper areas with sand substrate type and water currents moderate and fast. Phalloceros caudimaculatus occupied shallow and shaded areas with litter substrate type, and waters with slow current in the right edge of the stream.

It was not possible to do the $\mathrm{x}^{2}$ test in the vertical position variable for Characidium spp., Corydoras barbatus and Rineloricaria kronei because these species used almost exclusively the stream bottom.

The similarity analysis of spatial occupation of species allowed us to determine four groups: "lambaris", Characidium spp. and Rineloricaria kronei (group A), used the bottom in deep sites and waters with current more than $0.25 \mathrm{~m} . \mathrm{s}^{-1}$; Pimelodella pappenheimi and Corydoras barbatus (group B), occurred the bottom in sites with lower current (until 0.25 $\mathrm{m} . \mathrm{s}^{-1}$ ) and litter substrate type; Phalloceros 


\section{TABLE 1}

Fish species collected and/or observed in the "Mergulhão" stream during the study, and the codes used in the results of microhabitat or diet

Species

Family Erythrinidae

Hoplias malabaricus (Bloch, 1794)

Family Characidae

Characidium lanei Travassos, 1967

Characidium pterostictum Gomes, 1947

Oligosarcus hepsetus (Cuvier, 1817)

Mimagoniates microlepis (Steindachner,1876)

Astyanax sp.

Deuterodon langei Travassos, 1957

Family Pimelodidae

Microglanis sp.n *

Heptapteros mustelinus Valenciennes, 1840

Pimelodella pappenheimi Ahl, 1928

Rhamdia quelen (Quoy \& Gaimard, 1824)

Family Trichomycteridae

$$
\text { Homodiaetus sp.n * }
$$

Family Callichthyidae

Corydoras barbatus (Quoy \& Gaimard, 1824)

Family Loricariidae

Hemipsilichthys sp.n *

Kronichthys subteres Ribeiro, 1908

Hisonotus leucofrenatus (Ribeiro, 1908)

Pseudotothyris obtusa (Ribeiro, 1911)

Schizolecis guntheri Britski \& Garavelo, 1984

Rineloricaria kronei (Ribeiro, 1911)

Ancistrus sp.

Family Gymnotidae

Gymnotus pantherinus Steindachner, 1908

Family Poeciliidae

Phalloceros caudimaculatus (Hensel, 1868)

Family Cichlidae

Cichlasoma facetum (Jenyns, 1842)

Crenicichla sp.n *

Geophagus brasiliensis (Quoy \& Gaimard, 1824)

Family Synbranchidae

Synbranchus marmoratus Bloch, 1795

“*” new species that are being described.

caudimaculatus (group C) occupied shallow sites and waters with little current; and Mimagoniates microlepis (group D), the surface of water column.

Species with few records were not analysed statistically and their results were just descriptive.

Geophagus brasiliensis occurred in the left edge of the stream, upon litter and trunks and branches, in shaded areas.
Microhabitat codes Diet codes

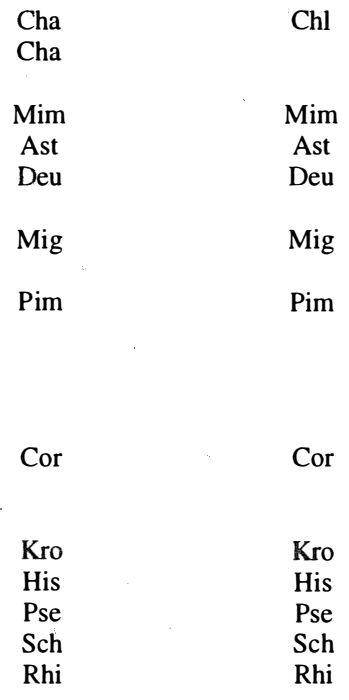

Pha

Pha
Kronichthys subteres and Microglanis sp. were not seen during underwater observations. However, during the samplings, they always occupied microhabitats formed by branches, leaves and other accumulated materials in fallen branches in the water, which suggests their preference for these microhabitats. Furthermore, there were few individuals, in the right margin of the stream in the middle of the grass. Hoplias malabaricus, Gymnotus 
TABLE 2

The significant differences in the habitat use, by species and by assemblage, in each environmental variable category, compared with the environmental availability, and its mainly occurrence

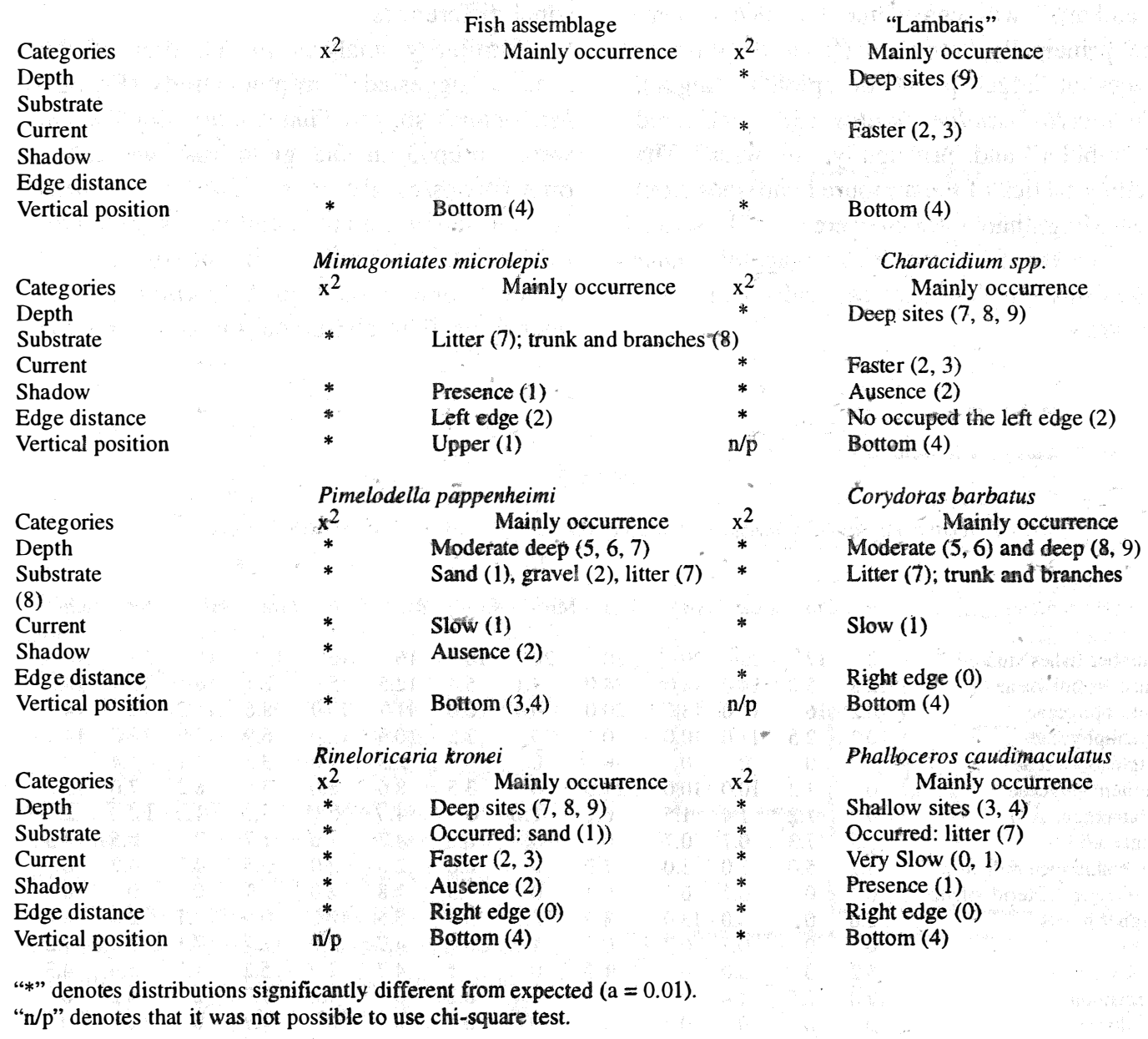

pantherinus and Synbranchus marmoratus preferred places next to the riparian vegetation.

Hisonotus leucofrenatus, Pseudotothyris obtusa and Schizolecis guntheri had few records during the observations. Nevertheless, they occupied the bottom, in depths varying from 40.5 to $88.0 \mathrm{~cm}$ and preferred the edges of the stream.

Crenicichla sp. and Oligosarcus hepsetus were observed in deep microhabitats in the middle of the water column.
Homodiaetus sp. was collected in a small area of rapids of the stream.

Feeding Behavior: The foraging tactic of Mimagoniates microlepis was considered as "surface picker", picking up floating organisms in the surface: Characidium spp. were considered as "sit-and-wait predators", sedentary fishes that ambush prey. Corydoras barbatus and Rineloricaria kronei were considered as "grubers", excavating the substrate 
and the characteristic "shallow environment" can have distinct magnitude.

$P$. caudimaculatus preferred to occupy the shallow edges of the stream almost without current. These results confirm the description made by Teixeira (1989), Sabino \& Castro (1990) and Aranha \& Caramaschi (in prep.) about the distribution of this species in coastal streams in Rio Grande do Sul, São Paulo and Rio de Janeiro, respectively.

The microhabitats occupied by "lambaris", Characidium spp. and Pimelodella pappenheimi were similar to those indicated by Sabino \& Castro (1990) respectively for Deuterodon iguape, Characidium sp. and Rhamdella minuta. These pairs of species belonging to the same subfamilies, and may execute similar functions as a reflex of the common evolutionary history of these groups.

Loricariidae and Callichthyidae studied fishes occupied mainly the bottom of the stream and the edge with vegetation. These results agree with those from Teixeira (1989) for some loricariids and for Corydoras paleatus, and with those from Aranha et al. (1993) for two others Corydoras species. Probably, this preferential microhabitat is characteristic in these groups.

The study of stomach contents indicated high frequency of algae in most of the species. Probably it is due to the availability of this resource in the "Mergulhão" stream.

The collected number of Hoplias malabaricus and Oligosarcus hepsetus was quite small and the stomach contents of these species were not studied. In the literature, these species have been appointed as piscivorous (e.g. Costa 1987, Teixeira 1989). We suppose that these species, together with Synbranchus marmoratus, constitute a piscivorous guild in the "Mergulhão" stream.

The comparative analysis of the trophic and habitat use guilds showed that the grouping of species was different, suggesting resource partitioning by the species.

$D$. langei and Astyanax sp. were generalist in the food preference (omnivorous/herbivorous guild) and in the habitat use too.
Herbivorous guild occupied the bottom and the edge of the stream, except $K$. subteres (which used a microhabitat similar to Microglanis sp.) and Rineloricaria kronei (which occupied the bottom in deep sites in unshaded areas).

P. caudimaculatus was a specialist in the habitat use and food. It constituted a spatial and a trophic guild by itself.

These results did not elucidate the theoretical question if stream fish assemblages are organized by deterministic processes such as competition. However, the fish assemblage of the "Mergulhão" stream does not have a random pattern of the habitat use, in opposition to the random organization whose some authors believe in (e.g. Matthews 1982).

We conclude that the differences in the spatial and trophic guilds in the "Mergulhão" stream make possible the segregation of these resources. If the competition is an important ecologic factor in this stream, the spatial and food partitioning should guarantee the coexistence of these species in the "Mergulhão" stream.

\section{ACKNOWLEDGMENTS}

The authors thank Marrcia S. de Menezes who helped us dúring sampling; Márcia S. de Menezes and Virgínia S. Uieda for reading the manuscript; Carlos S. Lucena and the staff of ichthyologists of the PUCRS for identifying several fish species; Julio C. Garavelo (UFSCar) for identifying Hypoptopomatinae; Francisco Langeani (UNESP/São José do Rio Preto) for identifying Rineloricaria and the $\mathrm{CNPq}$ for the scholarships to the junior authors.

\section{REFERENCES}

Aranha, J.M.R., E.P. Caramaschi \& U. Caramaschi. 1993. Ocupação espacial, alimentação e época reprodutiva de duas espécies de Corydoras (Siluroidei, Callichthyidae) coexistentes no rio Alambari (Botucatu, SP). Rev. bras. Zool. 10: 453-466. 
Connor, E.F. \& D.S. Simberloff: 1979. The assembly of species communities: change or competition? Eco$\operatorname{logy} 60: 1132-1140$.

Costa, W.J.E.M. 1984. Peixes fluviais do sistema lagunar de Maricá, Rio de Janeiro, Brasil. Atlântica, Rio Grande 7: 65- 72.

Costa, W.J.E.M. 1987. Feeding habitats of a fish community in a tropical coastal stream, Rio Mato Grosso, Brazil. Stud. Neotrop. Fauna Environ. 22: 145-153.

Gorman, O.T. 1988. The dynamics of habitat use in a guild of Ozark minnows. Ecol. Monog. 58: 1-18.

Gorman, O.T. \& J.R. Karr. 1978. Habitat structure and stream fish communities. Ecology 59: 507-515.

Grossman, G.D. \& A. de Sostoa. 1994. Microhabitat use by fish in the lower Rio Matarraña, Spain, 19841987. Ecol. Freshw. Fish 3: 123-136.

Grossman, G.D., P.B. Moyle \& J.O. Whitaker Jr. 1982. Stochascity in structural and functional characteristics of an Indiana stream fish assemblage: A test of community theory. Am. Nat. 120: 423-454.

Horn, M.H. 1972. The amount of space available for marine and freshwater fishes. Am. Nat. 70: 1295-1297.

Hyslop, E.J. 1980. Stomach contents analysis - a review of methods and their application. J. Fish Biol. 17 411-429.

Krebs, C.J. 1989. Ecological Methodology. Harper \& Row, New York. 654p

Lowe-McConnell, R.H. 1987. Ecological Studies in Tropical Fish Communities. Cambridge University, Cambridge, XIII+382p.
Matthews, W.J. 1982. Small fish community structure in Ozark streams: Structured assembly patterns or random abundance of species? Amer. Midl. Nat. 107: 42-54.

Romesburg, H.C. 1990. Cluster Analysis for Researches. Robert E. Krieger, 334p.

Ross, S.T. 1986. Resource partitioning in fish assemblages: a review of field studies. Copeia 1986: 352-388.

Sabino, J. \& R. M. C. Castro. 1990. Alimentação, período de atividade e distribuição espacial dos peixes de um riacho da Floresta Atlântica (Sudeste do Brasil). Rev. brasil. Biol. 50: 23-36.

Sazima, I. 1986. Similarities in feeding behaviour between some marine and freshwater fishes in two tropical communities. J. Fish Biol. 29: 53-65.

Schoener, T.W. 1974. Resource partitioning in ecological communities. Science 185: 27-38.

Smith, E.P. \& T.M. Zaret. 1982. Bias in estimating niche overlap. Ecology 63: 1248-1253.

Strong, D.R. 1980. Null hypothesis in ecology. Synthese 43: $271-285$.

Teixeira, R.L. 1989. Aspectos da ecologia de alguns peixes do arroio Bom Jardim, Triunfo-RS. Rev. brasil. Biol. 49: 183-192.

Yant, P.R., J.R. Karr \& P.L. Angermeier. 1984. Stochasticity in stream fish communities: an alternative interpretation. Am Nat. 124: 573-582.

Wiens, J.A. 1977. On competition and variable enviroments. Am. Sci. 65: 590-597. 